\title{
EFFECTS OF ARTIFICIAL DESTRATIFICATION ON ZOOPLANKTON \\ OF TWO OKLAHOMA RESERVOIRS
}

\author{
By \\ NANCY LYNN MCCLINTOCK \\ Bachelor of Science \\ Lamar University \\ Beaumont, Texas
}

1974
Submitted to the Faculty of the Graduate College of the Oklahoma State University
in partial fulfillment of the requirements
for the Degree of
MASTER OF SCIENCE
July, 1976


Thesis 1976

Ml65e

cop. 2 


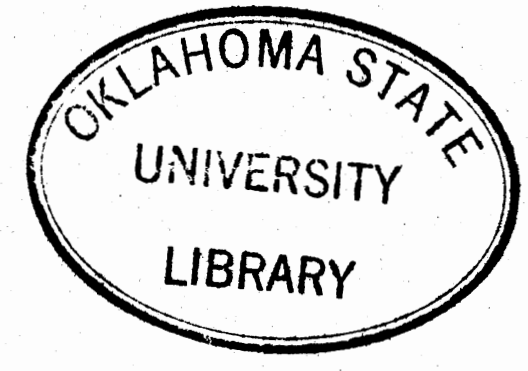

EFFECTS OF ARTIFICIAL DESTRATIFICATION ON ZOOPLANKTON

OF TWO OKLAHOMA RESERVOIRS

Thesis Approved:

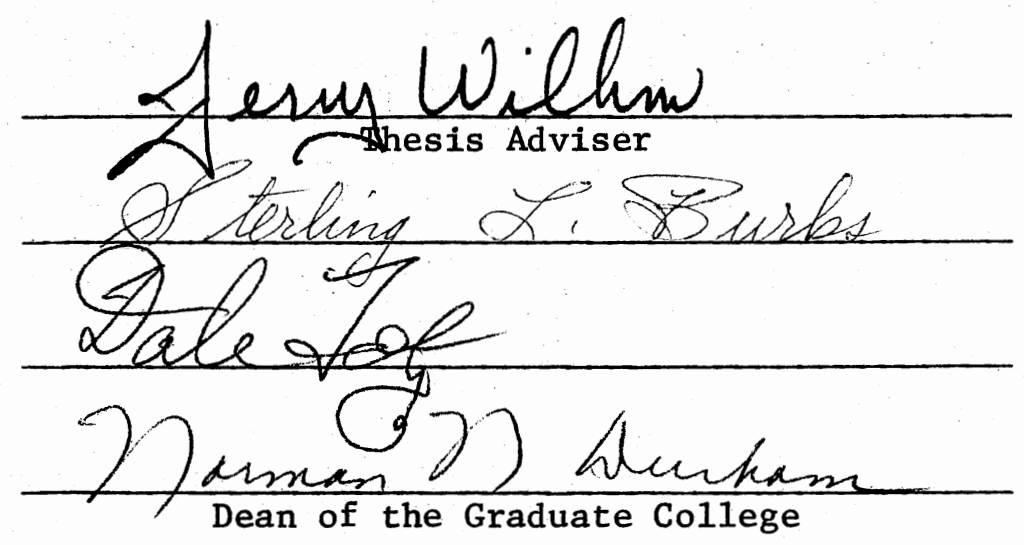

953364 
ACKNOWLEDGMENTS

I wish to thank Dr. Jerry Wilhm, my thesis adviser, for his time and effort throughout my research project. Appreciation is also extended to Dr. Bud Burks and Dr. Dale Toetz for advice and criticism of the manuscript, and to Dick Beatty and Car1 Ferraris for assistance and counsel in field and laboratory analysis.

Special thanks are extended to Dr. Richard Harrel and to my parents, Dan and Beverly McClintock, and family for their love and encouragement in this and a11 endeavors.

This study was part of a more extensive research effort to determine effects of artificial destratification on Ham's Lake and Arbuckle Lake, and was supported by the Oklahoma Water Resources Research Institute and the Bureau of Reclamation. 


\section{TABLE OF CONTENTS}

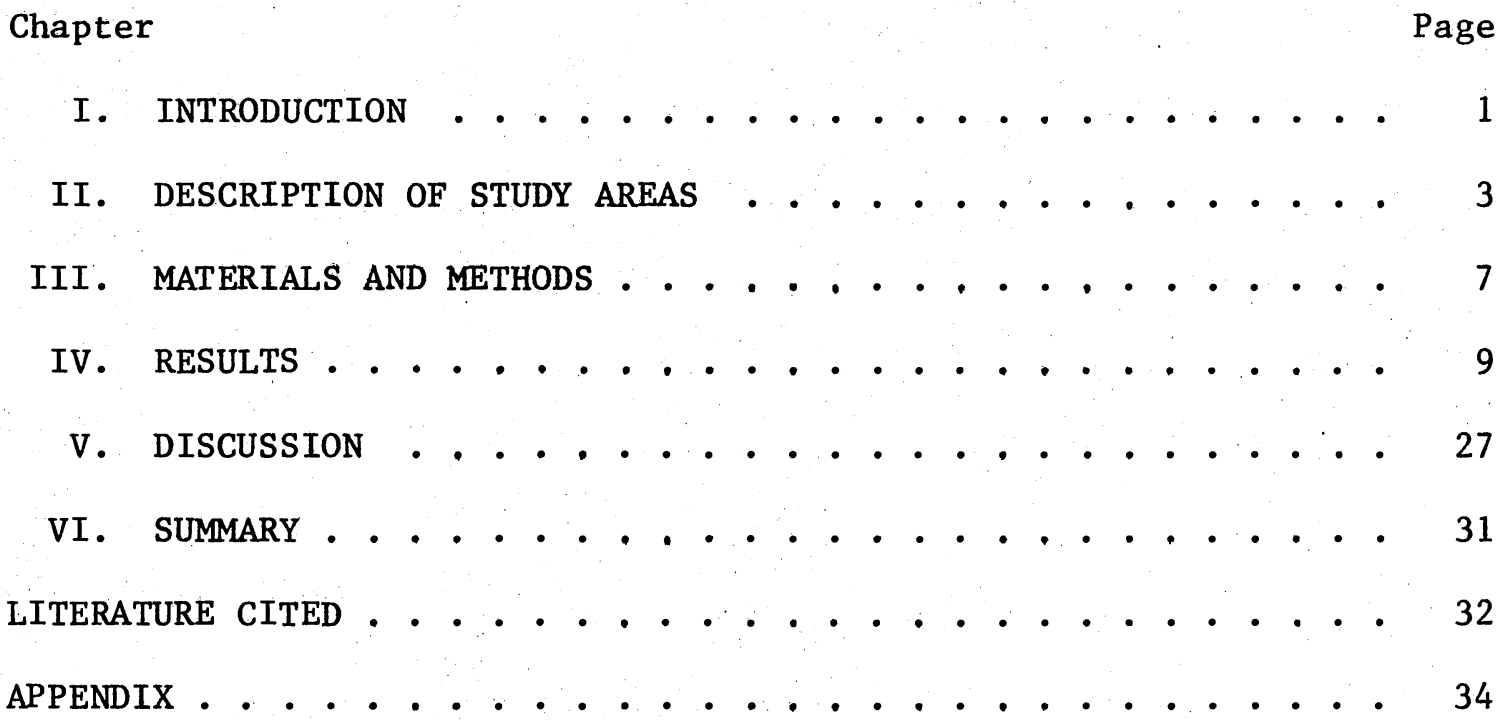


LIST OF TABLES

Table

Page

I. Physicochemical Conditions at Different Depths of a Water Column in the Central Pool During 1975 in Ham's Lake . . . . . . . . . . . . . . . .

II. Physicochemical Conditions at Different Depths of a Water Column in the Central Pool During 1975 in Arbuckle Lake . . . . . . . . . . . . . . .

III. Zooplankton Collected in Ham's Lake from April to August, 1975 . . . . . . . . . . . . . . .

IV. Number of Species of Zooplankton by Depth at Station 6 During 1975 in Ham's Lake . . . . . . . . . .

V. Density (Numbers/1) of Zooplankton by Depth at Station 6 During 1975 in Ham's Lake . . . . . . . . . . 16

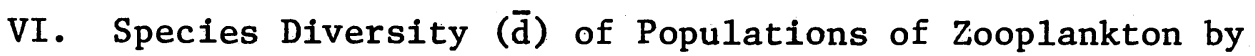
Depth at Station 6 During 1975 in Ham's Lake . . . . . .

VII. Zooplankton Collected in Arbuckle Lake from May to August, 1975 . . . . . . . . . . . . .

VIII. Number of Species of Zooplankton by Depth at Station A in Arbuckle Lake . . . . . . . . . . . . . . . .

IX. Density (Numbers/1) of Zooplankton by Depth at Station A During 1975 in Arbuckle Lake.

X. Species Diversity ( $\bar{d})$ of Populations of Zooplankton by Depth at Station A During 1975 in Arbuckle Lake . . . 26

XI. Density (Numbers/1) of Zooplankton by Depth in Ham's Lake on 12 Apr 75 . . . . . . . . . . . . . . 35

XII. Density (Numbers/1) of Zooplankton by Depth in Ham's Lake on 21 May 75 . . . . . . . . . . . . . . . .

XIII. Density (Numbers/1) of Zooplankton by Depth in Ham's Lake

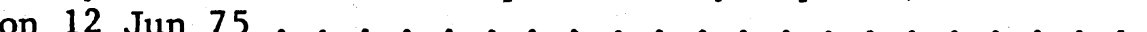


XIV. Density (Numbers/1) of Zooplankton by Depth in Ham's Lake on $2 \mathrm{Jul} 75$.................. 38

XV. Density (Numbers/1) of Zooplankton by Depth in Ham's Lake on 3 Aug 75 . . . . . . . . . . . . . 39

XVI. Density (Numbers/1) in Arbuckle Lake on 9 May $75 \ldots . . .40$

XVII. Density (Numbers/1) in Arbuckle Lake on 22 May 75 . . 41

XVIII. Density (Numbers/1) in Arbuckle Lake on 21 Jun 75 . . 42

XIX. Density (Numbers/1) in Arbuckle Lake on 8 Aug 75 . . . 43 


\section{LIST OF FIGURES}

1. Ham's Lake Showing Sampling Station ... . . . . . . . 4

2. Arbuckle Lake Showing Sampling Station . . . . . . . . 5

3. Density of Rotifera, Cladocera, Copepoda, and Ostracoda in Ham's Lake, Apr to Aug, 1975 . . . . . . . . . . 18

4. Density of Rotifera, Cladocera, and Copepoda in Arbuckle Lake, May to Aug, 1975 . . . . . . . . . . . 25 
CHAPTER I

\section{INTRODUCTION}

Zooplankton are important in fresh waters as a major trophic link between primary producers and higher forms. Their vertical distribution may be affected by temperature, dissolved oxygen, light intensity, and possibly $\mathrm{pH}$ and conductivity (Pennak 1953, Hutchison 1967). Motile forms select water layers of preferred temperature and non-motile forms do not survive at temperature layers outside their range of tolerance (Welch 1952, Ruttner 1963). Temperature also affects position of organisms in the water column by changing water density and viscosity and thus flotation (Welch 1952). Pennak (1953) reported that dissolved oxygen is seldom of significance in the distribution of cladocera except in the hypolimnion of lakes. Copepods are probably more tolerant of a deficiency of oxygen than cladocera. Photic sensitivity of plankters results in selection of certain light intensities and the phenomena of daily vertical migration (Ruttner 1963). The combined effects of all these factors are not fully understood.

The greatest vertical variation in the above parameters normally occurs during winter and summer stratification (Ruttner 1963, Hutchinson 1967). To prevent thermal layering and especially to avoid depletion of oxygen in the hypolimnion during these periods, lakes may be artificially destratified by aeration pumps or mixing propellar systems. Studies have been done to evaluate effects of these 
operations on water quality and aquatic life. Lackey (1973) found vertical distribution of zooplankton was basically unaffected in a destratified mountain lake in Parvin, Colorado, but biomass was reduced. Density increased following treatment in a small aerated lake in New Mexico (McNall 1971), while the opposite effect occurred at Lake Bret, Switzerland (Linder and Mercier 1954). Linder and Mercier also reported that increased concentrations of zooplankton in surface regions correlated with decreased light penetration during aeration. However, Fast (1971) found extended depth distribution of most zooplankters during destratification of E1 Capitan Reservoir and a tendency to concentrate along the bottom during the day. Zooplankton extended their depth distribution and increased in numbers, but did not concentrate along the bottom in a Michigan lake (Fast 1971a). The present study was designed for additional study of the relationships between destratification, water parameters, and zooplankton distribution.

Species diversity, $(\overline{\mathrm{d}})$, is a common measure for comparing biological data and evaluating changes. The species diversity index incorporates both richness of species and evenness and is little affected by rare species or sample size (Patten 1962). It is used in this study to describe zooplankton community structure throughout the project. 
CHAPTER II

DESCRIPTION OF STUDY AREAS

Ham's Lake

Ham's Lake was built by the Soil Conservation Service in 1965 as a flood detention reservoir (Figure 1). The lake drains approximately 1484.29 ha of loamy bottomland $8 \mathrm{~km} \mathrm{~W}$ of Stillwater, Oklahoma, in Payne County. The surface area of the lake is 40 ha and the volume is 115 ha $\mathrm{m}$ at principle spillway elevation of $287.0 \mathrm{~m}$ above sea level. The deepest point is approximately $9.5 \mathrm{~m}$.

Ham's Lake stratifies thermally and chemically in winter and summer. During summer the epilimnion is supersaturated, but dissolved oxygen is depleted within 3 to $4 \mathrm{~m}$ (Steichen 1974). In the summer of 1973, the lake was artificially destratified by a pump. Within 2 wk the lake was thermally destratified, but a longer period of time was necessary to destratify dissolved oxygen.

\section{Arbuckle Lake}

Arbuckle Lake is located in Murray County, Oklahoma, about $9.5 \mathrm{~km}$ SW of Sulphur (Figure 2). The lake was impounded in 1967 to serve for municipal water supply, flood control, fish and wildlife, and recreation (Gomez and Grinstead 1973). The surface area is 950 ha and the 

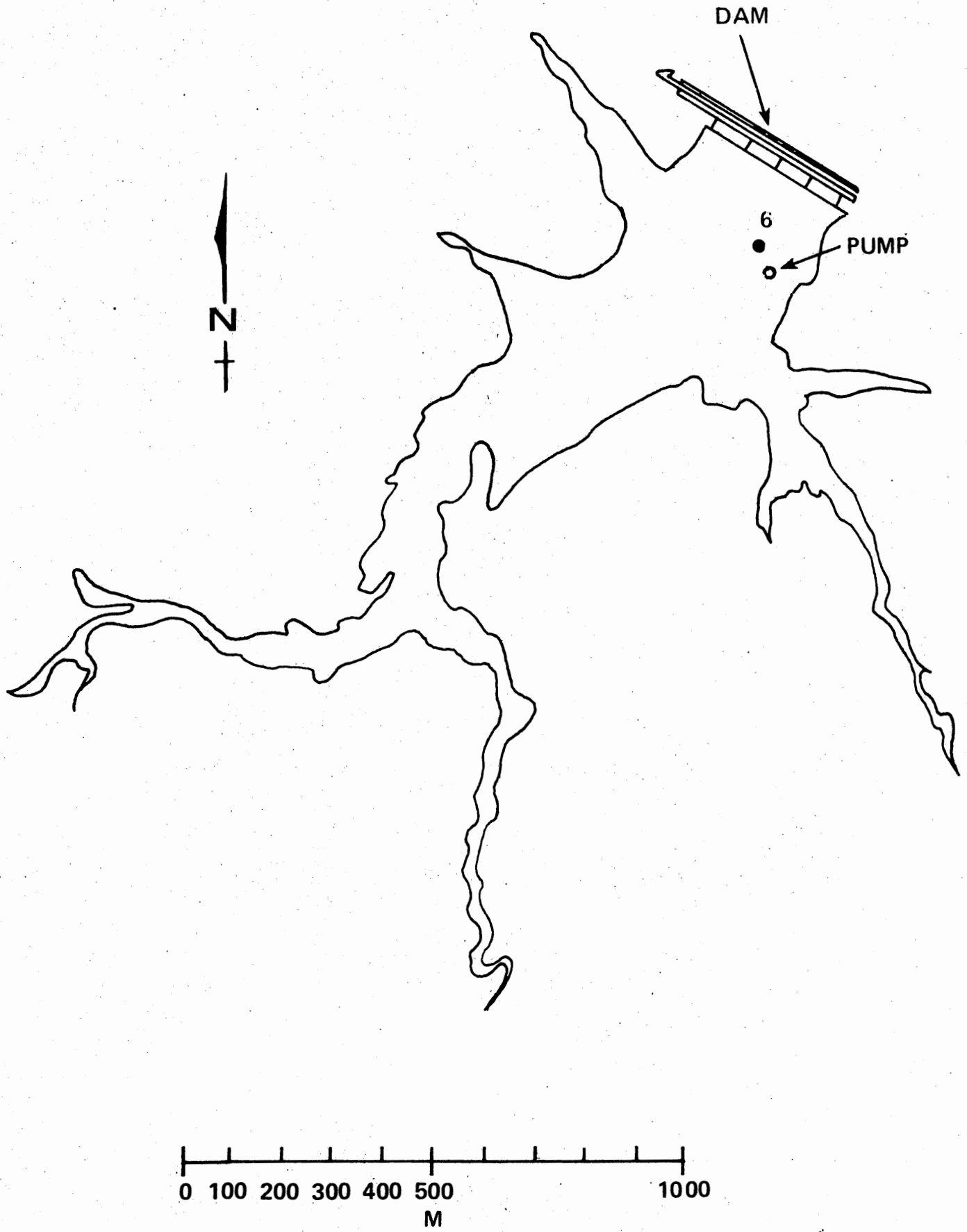

Figure 1. Ham's Lake Showing Sampling Station 

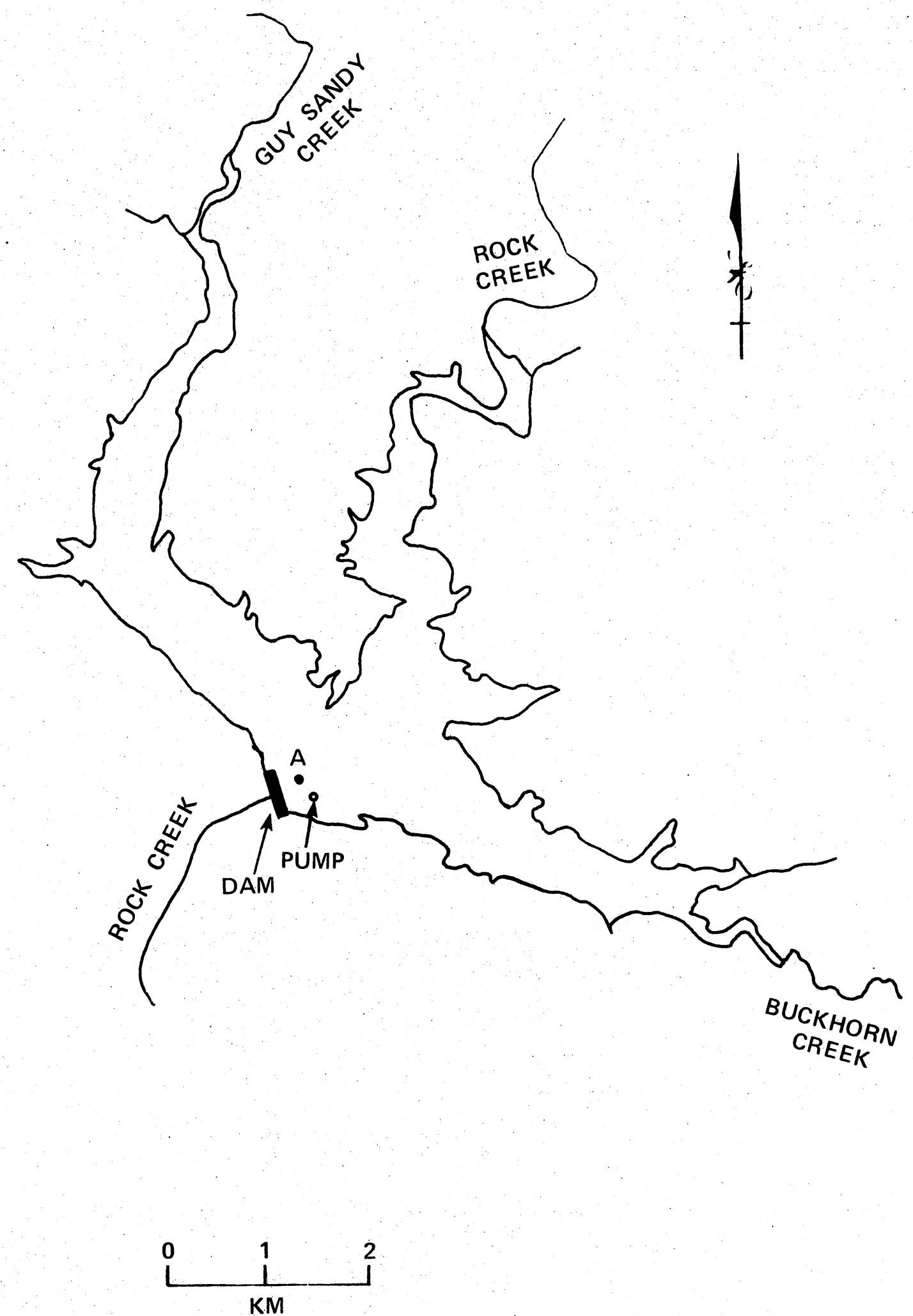

Figure 2. Arbuckle Reservoir Showing Sampling Station 
volume is 8930 ha $\mathrm{m}$. The deepest point of the lake is over $24 \mathrm{~m}$, and the length of the pool is almost $11 \mathrm{~km}$. The drainage area is $326 \mathrm{~km}^{2}$. 
CHAPTER III

MATERIALS AND METHODS

Ham's Lake Materials and Methods

Three samples each were taken with a Juday Plankton trap at the surface, $2,4,6$, and $8 \mathrm{~m}$ depths, approximately $100 \mathrm{~m} \mathrm{SW}$ of the destratification raft. Collections were made on 12 April, 21 May, and 12 June before the pumping started and on 2 July and 3 August afterwards. Samples were taken $5 \mathrm{~h}$ after sunrise and were preserved in $5 \%$ formalin. In the laboratory a sample was mixed and a $1 \mathrm{ml}$ subsample was examined on a Sedgewick-Rafter cell. A11 organisms in the cell were identified and counted. Additional cells were prepared until at least 200 organisms were identified. This was shown to be an adequate sample size for estimating diversity of zooplankton by Kochsiek et al. (1971). Because of time limitations, a maximum of 10 cells were analyzed for any sample. Zooplankton was identified to the lowest practical taxon using Ward and Whipple (1959), and Pennak (1953). Density (D) in organisms/1 was calculated by,

$$
D=\frac{(I)(C / A)}{F}
$$

where, $\quad I=$ number of individuals counted, $\mathrm{C}=$ volume $(\mathrm{m} 1)$ of concentrated sample, $A=$ number of Sedgewick-Rafter cells analyzed, 


$$
F=\text { liters of water sampled. }
$$

Species diversity ( $\bar{d})$ was determined by the equation of Shannon and Weaver (1963),

$$
\overline{\mathrm{d}}=-\sum_{1}^{s}\left(n_{i} / \mathrm{n}\right) \log _{2}\left(\mathrm{n}_{\mathrm{i}} / \mathrm{n}\right)
$$

where $n_{i}=$ number of individuals in the $i$ th taxon,

$\mathrm{n}=$ total numbers of individuals,

$\mathbf{s}=$ total number of species.

Three replicates each of temperature, dissolved oxygen, light penetration, conductivity, and $\mathrm{pH}$ were taken at each depth at each time period. A Yellow Springs Instruments (Y.S.I.) model 5525 oxygen meter was used to determine temperature and oxygen. Light penetration was measured with a G.M. Manufacturing model 268WA300 submarine photometer. Specific conductance was measured with a Y.S.I. model 33 salinityconductivity-temperature meter, and $\mathrm{pH}$ was measured with an Orion model 407 specific ion meter.

\section{Arbuckle Lake Materials and Methods}

Three samples each were taken with a Juday Plankton trap from the surface, $4,8,12,16,20$, and $24 \mathrm{~m}$ in the central pool. Collections were made on 9 May and 22 May before pumping started, and 21 June and 8 August afterwards. Samples were preserved and analyzed and physicochemical conditions were determined as described for Ham's Lake. 


\section{CHAPTER IV}

\section{RESULTS}

\section{Ham's Lake Physicochemical Conditions}

Temperature, dissolved oxygen, conductivity, and $\mathrm{pH}$ were relatively uniform in Ham's Lake on 12 April (Table I). By 21 May temperature, oxygen, and conductivity decreased with depth as the lake began to stratify. Greatest differences occurred between 2 and $4 \mathrm{~m}$. Vertical variation in $\mathrm{pH}$ was slight. By 12 June the lake exhibited a decrease of $7 \mathrm{C}$ in temperature from surface to bottom, $6.3 \mathrm{mg} / 1 \mathrm{in}$ oxygen, and 58 umho in conductivity. The cline was between 4 and $6 \mathrm{~m}$. On 3 July, 3 wk after pumping began, surface to bottom temperature and oxygen differences were reduced to $3.5 \mathrm{C}$ and $4.5 \mathrm{mg} / 1$, respectively. Conductivity was fairly uniform and $\mathrm{pH}$ exhibited a slight decrease with depth. By 3 August the lake was destratified chemically and thermally. Temperature was relatively uniform throughout and oxygen variation from surface to bottom was reduced to $1.7 \mathrm{mg} / 1$. Little variation existed in conductivity with a continued slight decrease with depth of pH. Light intensity decreased abruptly with depth on all dates it was measured. 
TABLE I

PHYSICOCHEMICAL CONDITIONS* AT DIFFERENT DEPTHS

OF A WATER COLUMN IN THE CENTRAL POOL

DURING 1975 IN HAM'S LAKE

\begin{tabular}{|c|c|c|c|c|c|c|}
\hline Date & $\begin{array}{c}\text { Depth } \\
\text { (m) }\end{array}$ & $\begin{array}{c}\text { Temperature } \\
\left({ }^{\mathrm{C}} \mathrm{C}\right)\end{array}$ & $\begin{array}{c}\text { Oxygen } \\
(\mathrm{mg} / 1)\end{array}$ & $\begin{array}{c}\text { Conductivity } \\
\text { (umhos) }\end{array}$ & $\mathrm{pH}$ & $\begin{array}{l}\text { Light } \\
\text { Intensity } \\
\text { (ua) }\end{array}$ \\
\hline $12 \mathrm{Apr}$ & $\begin{array}{c}\text { Surface } \\
2 \\
4 \\
6 \\
8\end{array}$ & $\begin{array}{l}13.2 \\
12.2 \\
12.0 \\
12.0 \\
11.5\end{array}$ & $\begin{array}{l}9.5 \\
9.5 \\
9.1 \\
8.8 \\
8.1\end{array}$ & $\begin{array}{l}297 \\
292 \\
291 \\
292 \\
301\end{array}$ & $\begin{array}{l}8.0 \\
7.8 \\
7.8 \\
7.9 \\
7.6\end{array}$ & $\begin{array}{l}* * \\
* * \\
* * \\
* * \\
* *\end{array}$ \\
\hline 21 May & $\begin{array}{c}\text { Surface } \\
2 \\
4 \\
6 \\
8\end{array}$ & $\begin{array}{l}22.5 \\
22.1 \\
18.4 \\
17.3 \\
16.2\end{array}$ & $\begin{array}{l}7.1 \\
7.0 \\
3.6 \\
3.3 \\
1.2\end{array}$ & $\begin{array}{l}328 \\
331 \\
320 \\
203 \\
215\end{array}$ & $\begin{array}{l}6.9 \\
6.9 \\
7.0 \\
7.0 \\
7.0\end{array}$ & $\begin{array}{l}* * \\
* * \\
* * \\
* * \\
* *\end{array}$ \\
\hline 12 Jun & $\begin{array}{c}\text { Surface } \\
2 \\
4 \\
6 \\
8\end{array}$ & $\begin{array}{l}23.5 \\
24.0 \\
23.8 \\
19.7 \\
16.5\end{array}$ & $\begin{array}{l}7.9 \\
7.8 \\
7.7 \\
1.8 \\
1.6\end{array}$ & $\begin{array}{l}327 \\
331 \\
333 \\
317 \\
269\end{array}$ & $\begin{array}{l}8.5 \\
8.5 \\
8.3 \\
7.7 \\
8.4\end{array}$ & $\begin{array}{r}9333 \\
182 \\
14 \\
0 \\
0\end{array}$ \\
\hline $2 \mathrm{Jul}$ & $\begin{array}{c}\text { Surface } \\
2 \\
4 \\
6 \\
8\end{array}$ & $\begin{array}{l}30.0 \\
27.0 \\
27.0 \\
26.5 \\
26.5\end{array}$ & $\begin{array}{l}6.8 \\
4.1 \\
3.1 \\
2.7 \\
2.3\end{array}$ & $\begin{array}{l}403 \\
410 \\
410 \\
410 \\
403\end{array}$ & $\begin{array}{l}8.1 \\
7.8 \\
7.6 \\
7.5 \\
7.5\end{array}$ & $\begin{array}{r}11,467 \\
243 \\
75 \\
0 \\
0\end{array}$ \\
\hline 3 Aug & $\begin{array}{c}\text { Surface } \\
2 \\
4 \\
6 \\
8\end{array}$ & $\begin{array}{l}29.3 \\
28.5 \\
28.5 \\
28.0 \\
28.0\end{array}$ & $\begin{array}{l}4.1 \\
3.1 \\
3.1 \\
3.0 \\
2.4\end{array}$ & $\begin{array}{l}395 \\
395 \\
398 \\
400 \\
400\end{array}$ & $\begin{array}{l}8.1 \\
7.8 \\
7.6 \\
7.5 \\
7.5\end{array}$ & $\begin{array}{r}11,333 \\
58 \\
1 \\
0 \\
0\end{array}$ \\
\hline
\end{tabular}

*Values are means of three measurements **Values not measured 
Arbuckle Lake Physicochemical Conditions

Arbuckle Lake was thermally and chemically stratified by 9 May with a vertical decrease of $12 \mathrm{C}$ in temperature and $4.6 \mathrm{mg} / 1$ in dissolved oxygen (Table II). Conductivity and $\mathrm{pH}$ also decreased with depth. These trends continued throughout the study with temperature increasing and oxygen decreasing despite aeration attempts. 0xygen decreased to $<1 \mathrm{mg} / 1$ at $16 \mathrm{~m}$ and below by 22 June and $<0.1 \mathrm{mg} / 1$ at a11 depths below $4 \mathrm{~m}$ on 8 August. Temperature, conductivity, and $\mathrm{pH}$ continued to decrease with depth throughout the study.

Ham's Lake Zooplankton

Twenty-five taxa of zooplankton were collected from Ham's Lake from April to August, including thirteen species of Rotifera, six species of Cladocera, and three species of Copepoda (Table III). Nauplii, copepodids, and the rotifer Keratella sp. maintained stable populations throughout the study. Conochilus sp. a colonial rotifer, was absent in April, extremely abundant in May, and almost absent in August. Polyarthra sp. was present in small numbers throughout the study, while Asplanchna sp. was collected primarily in May and June. Hexarthra sp. exhibited a peak in August when it became the dominant rotifer. Keratella sp. was the most consistently numerous rotifer in Ham's Lake.

The most abundant cladoceran collected was Ceriodaphnia lacustris. C. 1acustris and Bosmina 1ongirostris were present in May, June, and July, the former peaking in June and the latter in July. Both were rare in April and August. Diaphanosoma leuchtenbergianum exhibited 
TABLE II

PHYSICOCHEMICAL CONDITIONS* AT DIFFERENT DEPTHS OF A WATER COLUMN IN THE CENTRAL POOL DURING 1975 IN ARBUCKLE LAKE

\begin{tabular}{|c|c|c|c|c|c|}
\hline Date & $\begin{array}{l}\text { Water } \\
\text { Depth } \\
\text { (m) }\end{array}$ & $\begin{array}{c}\text { Temperature } \\
\left({ }^{\circ} \mathrm{C}\right)\end{array}$ & $\begin{array}{l}\text { Oxygen } \\
\text { (mg/1) }\end{array}$ & $\begin{array}{c}\text { Conductivity } \\
\text { (umhos) }\end{array}$ & $\mathrm{pH}$ \\
\hline 9 May & $\begin{array}{r}0 \\
4 \\
8 \\
12 \\
16 \\
20 \\
24\end{array}$ & $\begin{array}{l}24.5 \\
21.2 \\
19.0 \\
17.0 \\
15.2 \\
13.0 \\
12.0\end{array}$ & $\begin{array}{l}6.1 \\
1.6 \\
1.4 \\
1.4 \\
1.5 \\
1.6 \\
1.5\end{array}$ & $\begin{array}{l}395 \\
387 \\
361 \\
346 \\
348 \\
331 \\
330\end{array}$ & $\begin{array}{l}8.4 \\
8.4 \\
8.0 \\
7.9 \\
7.8 \\
7.6 \\
7.7\end{array}$ \\
\hline 23 May & $\begin{array}{r}0 \\
4 \\
8 \\
12 \\
16 \\
20 \\
24\end{array}$ & $\begin{array}{l}23.4 \\
23.1 \\
21.1 \\
17.1 \\
15.9 \\
14.0 \\
13.0\end{array}$ & $\begin{array}{l}8.2 \\
8.0 \\
5.2 \\
3.5 \\
3.8 \\
3.8 \\
1.9\end{array}$ & $\begin{array}{l}406 \\
409 \\
410 \\
370 \\
350 \\
352 \\
352\end{array}$ & $\begin{array}{l}8.4 \\
8.5 \\
8.1 \\
7.9 \\
8.0 \\
7.4 \\
7.5\end{array}$ \\
\hline 22 Jun & $\begin{array}{r}0 \\
4 \\
8 \\
12 \\
16 \\
20 \\
24\end{array}$ & $\begin{array}{l}26.0 \\
26.0 \\
24.1 \\
22.4 \\
21.0 \\
20.4 \\
18.9\end{array}$ & $\begin{array}{l}7.3 \\
7.2 \\
3.9 \\
2.2 \\
0.2 \\
0.1 \\
0.1\end{array}$ & $\begin{array}{l}390 \\
390 \\
390 \\
379 \\
388 \\
382 \\
285\end{array}$ & $\begin{array}{l}8.5 \\
8.4 \\
8.2 \\
7.9 \\
8.1 \\
7.9 \\
8.0\end{array}$ \\
\hline 8 Aug & $\begin{array}{r}0 \\
4 \\
8 \\
12 \\
16 \\
20 \\
24\end{array}$ & $\begin{array}{l}30.1 \\
27.1 \\
25.1 \\
24.9 \\
24.0 \\
23.5 \\
23.0\end{array}$ & $\begin{array}{r}8.0 \\
5.1 \\
<0.1 \\
<0.1 \\
<0.1 \\
<0.1 \\
<0.1\end{array}$ & $\begin{array}{l}410 \\
410 \\
400 \\
396 \\
392 \\
391 \\
450\end{array}$ & $\begin{array}{l}8.5 \\
8.4 \\
8.2 \\
7.9 \\
8.1 \\
7.9 \\
8.0\end{array}$ \\
\hline
\end{tabular}

*Values are means of three measurements. 
TABLE III

ZOOPLANKTON COLLECTED IN HAM'S LAKE FROM APRIL TO AUGUST, 1975

\section{Rotifera}

Ploima

Brachionus sp.

Kellicottia sp.

Keratella sp.

Lecane sp.

Monostyla sp.

Trichocerca sp.

Asplanchna sp.

Polyarthra sp.

Synchaeta sp.

Flosculariaceae

Filinia sp.

Hexarthra sp.

Conochilus sp.

Unidentifiable species

Arthropoda

Cladocera

Diaphanosoma 1euchtenbergianum Fischer

Daphnia ambigua Scourfield

Daphnia parvula Fordyce

Ceriodaphnia lacustris Birge

Bosmina longirostris (0,F. Muller)

Kurzia latissima (Kurz)

Unidentifiable chydoridae

Ostracoda

Unidentifiable species

Copepoda

Diaptomus pallidus (Bottom)

Cyclops bicuspidatus Claus

Mesocyclops edax (S. A. Forbes)

Nauplii

Copepodites

Diptera

Chaoborus sp. 
sma11 peaks in May and July. Daphnia ambigua was the dominant cladoceran in April, but was not abundant. Daphnia parvula was collected only rarely. Ostracods were found at all depths on all dates except August. They were most abundant in July and August and were the most numerous organism inhabiting the $8 \mathrm{~m}$ depth by the end of the study.

Diaptomus pallidus was the dominant copepod during all sampling periods, maintaining a fairly stable population until August. Mesocyclops edax was rare except for a small peak in June. Cyclops bicuspidatus was rarely seen in upper lake strata in May. Copepodids and naup1ii were collected in great numbers throughout the study, but most abundantly in May, June, and July. Nauplii were the most commonly and abundantly collected form in Ham's Lake.

Total number of species at any depth ranged from five to 16 (Table IV). The greatest number of species was found on 21 May at $4 \mathrm{~m}$. No correlation between depth and number of species was noted. However, a reduction of species at 6 and $8 \mathrm{~m}$ on 21 May and 12 June may possibly reflect limited oxygen concentrations (Table I). Temporal changes in species numbers appear to be related to seasonal population dynamics of the zooplankton species rather than destratification, since numbers decrease greatly in August despite little change in measured water quality parameters (Table I).

Total density by depth and season ranged from 38 to 505 individuals/1 (Table v). The maximum density at $2 \mathrm{~m}$ on 21 May was due largely to an abundance of Conochilus sp. a colonial rotifer. Density was generally greatest at $2 \mathrm{~m}$ and lowest at 6 or $8 \mathrm{~m}$. An abrupt increase occurred between 12 April and 21 May at all depths. Abrupt 
TABLE IV

NUMBER OF SPECIES* OF ZOOPLANKTON BY DEPTH

AT STATION 6 DURING 1975 IN

HAM'S LAKE

\begin{tabular}{cccc|cc}
\hline $\begin{array}{c}\text { Depth } \\
\text { (m) }\end{array}$ & $\begin{array}{c}12 \\
\text { Apr }\end{array}$ & $\begin{array}{l}21 \\
\text { May }\end{array}$ & $\begin{array}{c}12 \\
\text { Jun }\end{array}$ & $\begin{array}{c}2 \\
\text { Jul }\end{array}$ & $\begin{array}{c}3 \\
\text { Aug }\end{array}$ \\
\hline Surface & 6 & 15 & 13 & 12 & 10 \\
2 & 9 & 15 & 15 & 15 & 7 \\
4 & 6 & 16 & 13 & 14 & 9 \\
6 & 5 & 13 & 10 & 16 & 6 \\
8 & 7 & 13 & 11 & $13 * *$ & $9 * *$ \\
\hline
\end{tabular}

*Values are numbers of species in three Juday plankton trap samples (**0nly two samples analyzed)

Vertical line designates beginning of pumping (i.e. 19 Jun 75) 
TABLE V

DENSITY (NUMBERS/1) OF ZOOPLANKTON BY DEPTH AT STATION 6 DURING 1975 IN

HAM'S LAKE

\begin{tabular}{cccc|cc}
\hline $\begin{array}{c}\text { Depth } \\
(\mathrm{m})\end{array}$ & $\begin{array}{l}12 \\
\text { Apr }\end{array}$ & $\begin{array}{l}21 \\
\text { May }\end{array}$ & $\begin{array}{c}12 \\
\text { Jun }\end{array}$ & $\begin{array}{c}2 \\
\text { Jul }\end{array}$ & $\begin{array}{c}3 \\
\text { Aug }\end{array}$ \\
\hline Surface & 50 & 362 & 229 & 384 & 72 \\
2 & 94 & 505 & 299 & 476 & 58 \\
4 & 38 & 241 & 267 & 206 & 54 \\
6 & 54 & 226 & 75 & 177 & 37 \\
8 & 47 & 236 & 68 & $171 * *$ & $98 * *$ \\
\hline
\end{tabular}

*Values are mean densities of three Juday plankton trap samples (**Only two samples analyzed)

Vertical line designates beginning of pumping (i.e. 19 Jun 75) 
decreases in density between 2 and $4 \mathrm{~m}$ on 21 May and 4 and $6 \mathrm{~m}$ on 12 June possibly reflected low dissolved oxygen concentrations. Density tended to increase shortly after pumping began and to decrease abruptly between $2 \mathrm{Ju} 1 \mathrm{y}$ and 3 August. In August, the highest density was at $8 \mathrm{~m}$ due largely to an abundance of ostracods.

The percent of the total population at $6 \mathrm{~m}$ and below was $35,29,15$, 25, and 42 for the five sampling dates, respectively. Temporal variation in the density of rotifers was greater than that of other groups (Figure 3). Rotifer density peaked on 21 May, while cladoceran and copepod density peaked on 12 June and 2 July, respectively. Species diversity $(\bar{d})$ of zooplankton ranged from 1.5 to 2.9 (Table VI). Minimum diversity was most often observed at the surface, while maximum diversity occurred most of ten at the middle depths. No correlations were observed between diversity and depth, or diversity and physicochemical conditions.

\section{Arbuckle Lake Zooplankton}

Since pumping did not destratify Arbuckle Lake, changes in the zooplankton population can be attributed to seasonal effects. Twentyfour taxa of zooplankton were collected from the lake from May to August, including ten species of Rotifera, five species of Cladocera, and seven species of Copepoda (Table VII). As in Ham's Lake, Keratella $\mathrm{sp}$. was the most commonly abundant rotifer, with a peak on 22 May. One species of Trichocerca was fairly abundant on 22 May, but was collected at other periods only rarely. Polyarthra sp. also peaked on 22 May, but was collected at other periods in smaller numbers. Conochilus sp. was found on 9 May at a relatively high density of 347 individuals/1 at 


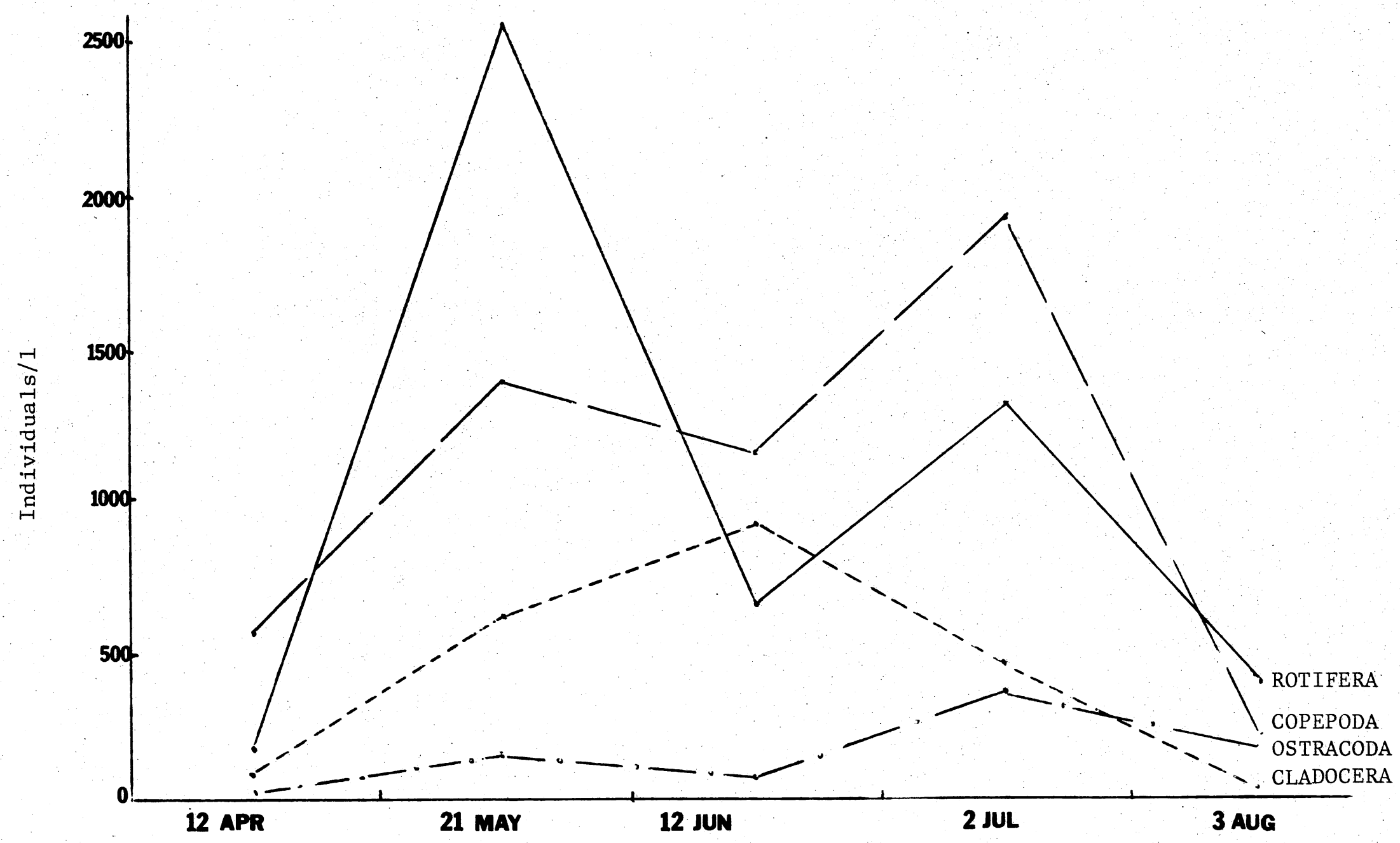

Figure 3. Density of Rotifera, Cladocera, Copepoda, and Ostracoda in Ham's Lake, Apr to Aug, 1975 


\section{TABLE VI}

SPECIES DIVERSITY $(\overline{\mathrm{d}}) *$ OF POPULATIONS OF ZOOPLANKTON

BY DEPTH AT STATION 6 DURING 1975 IN HAM'S LAKE

\begin{tabular}{cccc|cc}
\hline $\begin{array}{c}\text { Depth } \\
(\dot{\mathrm{m}})\end{array}$ & $\begin{array}{c}12 \\
\text { Apr }\end{array}$ & $\begin{array}{l}21 \\
\text { May }\end{array}$ & $\begin{array}{c}12 \\
\text { Jun }\end{array}$ & $\begin{array}{c}2 \\
\mathrm{JuI}\end{array}$ & $\begin{array}{c}3 \\
\text { Aug }\end{array}$ \\
\hline Surface & 1.5 & 1.8 & 2.1 & 2.3 & 2.3 \\
2 & 2.0 & 1.9 & 2.3 & 2.8 & 2.4 \\
4 & 1.9 & 2.2 & 2.9 & 2.9 & 2.3 \\
6 & 1.2 & 2.0 & 2.8 & 2.9 & 2.3 \\
8 & 1.9 & 2.3 & 2.2 & $2.5 * *$ & $2.2 * *$ \\
\hline
\end{tabular}

*Values are total diversity of three pooled samples

(**0nly two samples analyzed)

Vertical line designates beginning of pumping (i.e. 19 Jun 75) 
TABLE VII

ZOOPLANKTON COLLECTED IN ARBUCKLE LAKE

FROM MAY TO AUGUST, 1975

Rotifera

Ploima

Keratella sp.

Trichocerca sp. 1

Trichocerca sp. 2

Asplanchna sp.

Polyarthra sp.

Synchaeta sp.

Flosculariaceae

Filinia sp.

Hexarthra sp.

Conochiloides sp.

Conochilus sp.

Arthropoda

Cladocera

Diaphanosoma leuchtenbergianum (Fischer)

Daphnia ambigua Scourfield

Daphnia parvula Fordyce

Ceriodaphnia lacustris Birge

Bosmina longirostris (0. F. Muller)

Ostracoda

Unidentifiable species

Copepoda

Diaptomus pallidus (Bottom)

Diaptomus siciloides Lillieborg

Tropocyclops prasinus (Fischer)

Cyclops bicuspidatus Claus

Mesocyclops edax (S. A. Forbes)

Harpacticoid copepod

Ergasilus chautauquaensis Fellows

Nauplii

Copepodites

Diptera

Chaoborus sp. 
$4 \mathrm{~m}$ and was collected only rarely later in the study. Asplanchna sp. also exhibited a maxima on 9 May, reaching a density of 42 individuals/1 at $4 \mathrm{~m}$ and was rarely collected later.

Bosmina longirostris was the most commonly collected cladoceran in Arbuckle Lake. It was present at all depths on a11 sampling dates, reaching a maximum on 21 June at $2 \mathrm{~m}$. Ceriodaphnia lacustris was present in small numbers at $4 \mathrm{~m}$ and below throughout the study. Daphnia parvula was present on 9 May but rare on later dates. Daphnia ambigua and Diaphanosoma leuchtenbergianum were rarely collected.

Nauplii and copepodids were the most numerous crustaceans in Arbuckle Lake. They were collected at all depths on all sampling dates and reached a maximum on 21 June. Both forms were most abundant between 4 and $16 \mathrm{~m}$. Diaptomus pallidus was found in small numbers, reaching a peak on 21 June. Diaptomus siciloides was present at $12 \mathrm{~m}$ and below on 9 May. Cyclops bicuspidatus was found in small numbers only on the first two sampling periods, reaching a maximum density of 22 individuals/1 at $24 \mathrm{~m}$ on 22 May. Tropocyclops prasinus and Mesocyclops edax were collected occasionally throughout the study at $4 \mathrm{~m}$ and below, although $\underline{\mathrm{T}}$. prasinus was absent on 22 May.

Total number of species by depth and season ranged from three to 15 (Table VIII), which was slightly lower than the range reported for Ham's Lake. As in Ham's Lake, no consistent relationship was observed between number of species and depth. Minimum numbers of species generally were collected at the surface, while maximum numbers occurred between 4 and $12 \mathrm{~m}$. Numbers of species did not reflect limiting oxygen concentrations in deeper waters in Arbuckle Lake (Table II). 
TABLE VIII

NUMBER OF SPECIES* OF ZOOPLANKTON BY DEPTH

AT STATION A IN ARBUCKLE LAKE

\begin{tabular}{ccc|cc}
\hline $\begin{array}{c}\text { Depth } \\
(\mathrm{m})\end{array}$ & $\begin{array}{c}9 \\
\text { May }\end{array}$ & $\begin{array}{l}22 \\
\text { May }\end{array}$ & $\begin{array}{l}21 \\
\text { Jun }\end{array}$ & $\begin{array}{c}8 \\
\text { Aug }\end{array}$ \\
\hline Surface & 6 & 9 & 7 & 6 \\
4 & 13 & 12 & 12 & 13 \\
8 & 14 & 10 & 9 & 11 \\
12 & 14 & 15 & 10 & 8 \\
16 & 13 & 11 & 11 & 8 \\
20 & 9 & 12 & 10 & 3 \\
24 & 13 & 9 & 10 & 6 \\
\hline
\end{tabular}

*Values are number of species in three Juday plankton trap samples. Vertical line designates beginning of pumping. 
Density ranged from 27 to 576 individuals/1 (Table IX), which is similar to the range for Ham's Lake. A slight tendency existed for density to decrease with depth; however, no apparent relationship existed between density and measured physicochemical conditions. Density tended to decrease with time. The highest percent of the total population at any sampling period was found at $2 \mathrm{~m}$. As in Ham's Lake, rotifers exhibited the greatest temporal variation in density, reaching a maximum on 9 May (Figure 4). Copepods were densest on 21 June, while cladocerans were fairly uniform throughout with a small peak on 21 June.

Species diversity $(\bar{d})$ of zooplankton varied from 1.2 to 3.1 (Table X). As in Ham's Lake, no relationship was observed between density and depth or between diversity and time. Minimum diversity was measured in the surface sample during three sampling periods. 
TABLE IX

DENSITY (NUMBERS/1)* OF ZOOPLANKTON BY DEPTH AT STATION A DURING 1975 IN ARBUCKLE LAKE

\begin{tabular}{ccc|cc}
\hline $\begin{array}{c}\text { Depth } \\
(\mathrm{m})\end{array}$ & $\begin{array}{c}9 \\
\text { May }\end{array}$ & $\begin{array}{c}22 \\
\text { May }\end{array}$ & $\begin{array}{c}21 \\
\text { Jun }\end{array}$ & $\begin{array}{r}8 \\
\text { Aug }\end{array}$ \\
\hline Surface & 39 & 210 & 84 & 30 \\
4 & 576 & 200 & 245 & 177 \\
8 & 362 & 84 & 127 & 74 \\
12 & 231 & 167 & 153 & 43 \\
16 & 242 & 142 & 208 & 76 \\
20 & 173 & 143 & 99 & 27 \\
24 & 178 & 145 & 135 & 35 \\
\hline
\end{tabular}

*Values are mean densities of three Juday plankton trap samples. Vertical line designates beginning of pumping. 


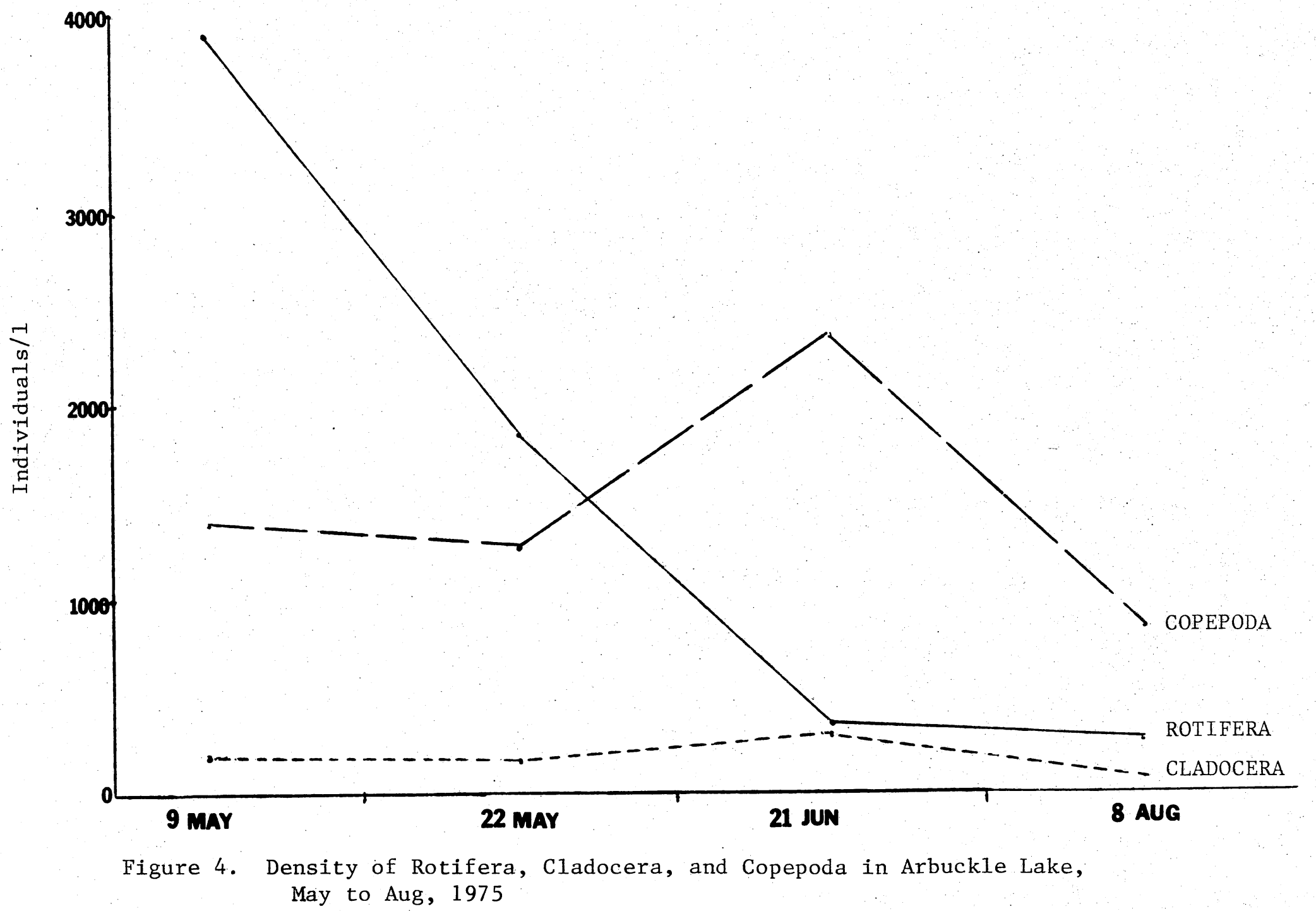


TABLE $\mathrm{X}$

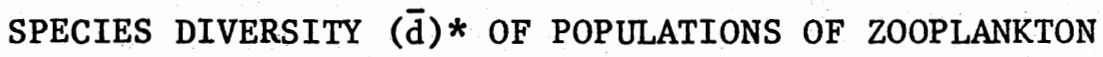

BY DEPTH AT STATION A DURING 1975 IN ARBUCKLE LAKE

\begin{tabular}{ccc|cc}
\hline $\begin{array}{c}\text { Depth } \\
(\mathrm{m})\end{array}$ & $\begin{array}{c}9 \\
\text { May }\end{array}$ & $\begin{array}{l}22 \\
\text { May }\end{array}$ & $\begin{array}{l}21 \\
\text { Jun }\end{array}$ & $\begin{array}{c}8 \\
\text { Aug }\end{array}$ \\
\hline Surface & 1.3 & 1.8 & 2.6 & 1.8 \\
4 & 1.8 & 2.3 & 3.1 & 3.0 \\
8 & 1.9 & 2.0 & 2.7 & 2.7 \\
12 & 1.8 & 2.8 & 2.9 & 2.5 \\
16 & 1.6 & 2.3 & 2.8 & 2.8 \\
20 & 1.4 & 2.6 & 2.7 & 1.2 \\
24 & 2.2 & 2.4 & 2.9 & 1.9 \\
\hline
\end{tabular}

*Values are total diversity of three pooled samples.

Vertical line designates beginning of pumping. 


\section{CHAPTER V}

\section{DISCUSSION}

Twenty-five and 24 taxa were taken from Ham's Lake and Arbuckle Lake, respectively, from May to August, 1975. Bowles (1973) collected 23 taxa from Eufaula Reservoir, while Kochsiek et al. (1971) collected 46 taxa in an annual study of Keystone Reservoir. Prather and Prophet (1968) collected 23, 20, and 23 taxa from John Redmond, Council Grove, and Marion Reservoirs, respectively, in Kansas. Most species collected in the present study have been commonly reported in Oklahoma and Kansas by other researchers (Duck 1936, Jones 1955, Kingsbury 1965, Prather and Prophet 1968, Robertson 1970, Kochsiek et a1. 1971, Bowles 1973, Prophet. and Waite 1975).

Keratella sp. was the most common rotifer in Ham's Lake and Arbuckle Lake, as well as in Eufaula (Bowles 1973), Marion, and Council Grove Reservoirs (Prather and Prophet 1968). The most abundant cladoceran in Ham's Lake was Ceriodaphnia lacustris, while Bosmina longirostris was the most abundant in Arbuckle Lake. $\underline{\text { C. }}$ lacustris was also the most common cladoceran in Eufaula Reservoir (Bowles 1973) and B. longirostris in John Redmond Reservoir (Prather and Prophet 1968). Immature copepoda were extremely abundant in both Ham's and Arbuckle Lake, and in Eufaula (Bowles 1973) and Keystone Reservoirs (Kochsiek et a1. 1971). Densities of the identified copepod species are underestimated since immatures are not identifiable to species and not 
included in estimates. Diaptomus pallidus, and Mesocyclops edax were the major copepods taken in Ham's Lake, while the copepod population in Arbuckles consisted primarily of $\underline{\text { D. pallidus, }}$ M. edax, Cyclops bicuspidatus, and Tropocyclops prasinus. In a study of 45 lakes, Patalas (1971) stated that a declining proportion of diaptomids and an increasing number of cyclopoids and cladocerans, as seen in Arbuckle Lake, characterizes lakes with increasing nutrient loads.

Densities averaged 175 and 157 individuals per liter in Ham's and Arbuckle Lake, respectively. This is considerably higher than that reported in Eufaula Reservoir, but within the range reported for Keystone Reservoir. The figures are not entirely comparable, however, since Wisconsin plankton nets were used in the latter studies and a Juday plankton trap was used in the present study. Filtration efficiencies vary greatly among methods.

Diversity of all samples averaged 2.2 in Ham's Lake and 2.3 in Arbuckle Lake. These values are lower than in most area reservoirs. Bowles (1973) found $\overline{\mathrm{d}}$ ranging from 2.16 to 2.96 in Eufaula Reservoir, while Kochsiek et al. (1971) found a mean $\overline{\mathrm{d}}$ of 2.96 for summer in Keystone Reservoir. For Redmond, Marion, and Council Grove, Prather and Prophet (1968) reported $\overline{\mathrm{d}}$ values of $2.57,2.50$, and 2.86 , respectively.

Seasonal variation of species number and density of zooplankton populations was similar in the two lakes. Mean number of species and density over all depths were relatively low in August in both lakes and in April in Ham's Lake. No April sample was taken in Arbuckle Lake. Maximum density occurred in May in both lakes. Seasonal variation in diversity was also similar in the two lakes. Diversity was low in 
April, tended to increase through the early summer sample, and then decreased in August. Although it is not possible to directly relate seasonal variation to physicochemical conditions, the low values in August may have been influenced by low concentrations of dissolved oxygen. Prather and Prophet (1968) reported that species diversity ( $\overline{\mathrm{d}}$ ) in Redmond, Council Grove, and Marion Reservoirs was not related to the measured physicochemical conditions.

The pronounced vertical variation in temperature and dissolved oxygen was not closely reflected in species composition and diversity of zooplankton. Density tended to be less at the lower depths than at the upper depths, possibly reflecting lower dissolved oxygen concentrations in the hypolimnion. Pennak (1953) stated that low dissolved oxygen concentrations may limit cladocerans in the hypolimnion of lakes. However, trends in vertical variation in numbers of species and in diversity were not observed.

Although pumping did not destratify Arbuckle Lake, it resulted in an increased dissolved oxygen concentration in the bottom waters of Ham's Lake. The variation in temperature between the surface and the bottom was only $1.3 \mathrm{C}$ by 3 August in Ham's Lake. Variation exists in the literature on the effects of artificial destratification on zooplankton populations. Fast (1971) reported that before destratification of E1 Capitan Reservoir, $85 \%$ of the zooplankton were restricted to the area above $10 \mathrm{~m}$, whereas after treatment $85 \%$ were below $10 \mathrm{~m}$. In contrast, Lackey (1973) reported that depth distribution of cladocera and rotifera in Parvin Lake were unaffected by artificial destratification. Linder and Mercier (1954) suggested that artificial destratification may increase the rate of light extinction by 
resuspending detritus, sediments, and other materials, and thus zooplankton may even relocate more toward the surface where their food source is restricted due to light requirements. Although this phenomenon was not observed in Ham's Lake, some response was noted. Only $15 \%$ of the total population was found at $6 \mathrm{~m}$ and below shortly before destratification, while $42 \%$ were found at $6 \mathrm{~m}$ and below in August when mixing was most pronounced. 


\section{CHAPTER VI}

\section{SUMMARY}

1. Zooplankton were collected from five depths of the central pool of Ham's Lake from April to August and from seven depths of the centra1 pool of Arbuckle Lake from May to August, 1975. Composition, density, and diversity were observed for variation in distribution with time and depth. Effects of artificial destratification on the zooplankton assemblage were also observed.

2. Twenty-five and twenty-four taxa were collected from Ham's and Arbuckle Lake, respectively. Species composition and density were similar to other area reservoirs, while diversity values $(\bar{d})$ were consistently lower.

3. No correlation was observed between depth and number of species or depth and diversity. There was a tendency for density to decrease with depth. Densities were lowest in April and August in Ham's Lake and in August in Arbuckles Lake. No April sample was taken in Arbuckle Lake. In both lakes, density was highest in May.

4. Ham's Lake was artificially destratified by the pumping, while Arbuckle Lake was not destratified during the study. Although some temporal variation in species numbers and densities possibly reflected limited oxygen concentrations, the changes could not be directly related to physicochemical conditions of the lakes. Variations are probably due in part to seasonal population dynamics of the zooplankton. No correlation was observed between diversity and time. 
Bowles, L. G. 1973. Influence of spatial heterogeneity on estimates of concentration and species diversity of pelagic net zooplankton. MS thesis, Okla. State Univ., 19 p.

Duck, L. G. 1937. Some copepods of Oklahoma. Proc. Okla. Acad. Sci., $17: 34-35$.

Fast, A. W. 1971. Effects of artificial destratification on zooplankton depth distribution. Trans. Amer. Fish Soc. 2:355-357.

Fast, A. W. 1971a. The effect of artificial aeration on lake ecology. Ph.D. diss., Michigan State Univ., E. Lansing. 566 p.

Gomez, R. and B. G. Grinstead. 1973. Reservoirs of Oklahoma. Okla. Fish Res. Lab., Bull. II, 129 p.

Hutchinson, G. E. 1967. A treatise on limnology, Vo1 II. John Wiley \& Sons Inc., New York. 1115 p.

Kingsbury, P. 1966. Distribution of spring Diaptomids (Copepoda: Calanoida) in Okla. Proc. Okla. Acad. Sci. 46:49-53.

Kochsiek, K. A., J. L. Wilhm, and R. Morrison. 1971. Species diversity of net zooplankton and physicochemical conditions in Keystone Reservoir, Okla. Ecology 52:1119-1125.

Lackey, R. T. 1973. Effects of artificial destratification on zooplankton in Parvin Lake, Colorado. Trans. Amer. Fish. Soc. 102:450-452.

Linder, C. P. and P. Mercier. 1954. Etude comparative de la repartition du zooplankton au Lac de Bret avant et apres raeration. Scweiz Zeitschr Hydro1. 16:309-317.

McNa11, W. J. 1971. Destratification of lakes. Job Progress Report Job C-8, Statewide Fisheries Invest. New Mexico Federal Aid Project No. F-22-R-11. 31 p.

Patalas, K. 1971. Crustacean plankton communities in forty-five lakes in the Experimental Lakes Area, Northwestern Ontario. J. Fish. Res. Board Canada 28:231-244.

Patten, B. C. 1962. Species diversity in net phytoplankton of Raritan Bay. J. Mar. Res. 20:57-75. 
Pennak, R. W. 1953. Freshwater invertebrates of the United States. Ronald Press, New York.

Prather, J. E. and C. W. Prophet. 1968. Zooplankton species diversity in John Redmond, Marion, and Council Grove Reservoirs, Kansas, summer 1968. Emporia State Res. Studies XVIII (1):5-16.

Prophet, C. W. and S. Waite. 1975. A species list of Cladocera and Copepoda in Kansas. Trans, of the Kansas Acad. Sci 77:42-47.

Riddick, T. M. 1957. Forced circulation of reservoir waters. Water and Sewage Works. 104:231-237.

Robertson, A. 1970. Distribution of Calanoid Copepods (Calanoida, Copepoda) Proc. Okla. Acad. Sci. 50:98-103.

Ruttner, Franz. 1963. Fundamentals of 1imnology. (3rd Ed.) (Translated by Frey and Fry) Univ. of Toronto Press, Toronto. 295 p.

Shannon, C. D. and W. Weaver. 1963. The mathematical theory of communication. Univ. Illinois Press, Urbana. 117 p.

Steichen, J.M. 1974. The effect of lake destratification on water quality parameters. Ph.D. Diss., Okla. State Univ., 108 p.

Ward, H. B. and G. C. Whipple. 1945. Fresh-water Biology. John Wiley \& Sons, Inc. New York, 1111 p.

Watson, N. H. F. and G. F. Carpenter. 1974. Seasonal abundance of crustacean zooplankton and net plankton biomass of lakes Huron, Erie, and Ontario. J. Fish. Res. Board Canada 31:309-317.

Welch, P. S. 1952. Limnology. 2nd ed. New York, McGraw-Hill Book Co. 469 p. 
APPENDIX 
TABLE XI

DENSITY (NUMBERS/1) OF ZOOPLANKTON BY DEPTH

IN HAM'S LAKE ON 12 APR 75

\begin{tabular}{|c|c|c|c|c|c|}
\hline \multirow[b]{2}{*}{ Taxa } & \multicolumn{5}{|c|}{ Depth (m) } \\
\hline & 0 & 2 & 4 & 6 & 8 \\
\hline Keratella sp. & 11 & 23 & 6 & 18 & 3 \\
\hline Monostyla sp. & $<1$ & $<1$ & & & \\
\hline Asplanchna sp. & & $<1$ & $<1$ & & \\
\hline Polyarthra sp. & $<1$ & 1 & & $<1$ & \\
\hline Filinia sp. & & & $<1$ & & \\
\hline Diaphanosoma leuch. & & & & & 1 \\
\hline Daphnia ambigua & & 6 & 2 & 3 & 15 \\
\hline Daphnia parvula & 1 & 2 & & & 1 \\
\hline Ceriodaphnia lacustris & $<1$ & $<1$ & & & \\
\hline Bosmina longirostris & & & $<1$ & & \\
\hline Nauplii & $30 *$ & $40 *$ & $23 *$ & $22 *$ & $21 *$ \\
\hline Ostracoda & & $<1$ & & $<1$ & 2 \\
\hline Diaptomus pallidus & 2 & 10 & 4 & 3 & 2 \\
\hline Mesocyclops edax & & & & & $<1$ \\
\hline Copepodites & $4 *$ & $10 *$ & $3 *$ & $7 *$ & $1 *$ \\
\hline $\begin{array}{l}\text { *These values included } \\
\text { total number of specie } \\
\text { unidentifiable, immatu } \\
\text { species. }\end{array}$ & spe & is & $\begin{array}{l}\text { usec } \\
\text { nce } \\
\text { not }\end{array}$ & $\begin{array}{l}\text { dete } \\
\text { are } \\
\text { sent }\end{array}$ & \\
\hline
\end{tabular}


TABLE XII

DENSITY (NUMBERS/1) OF ZOOPLANKTON BY DEPTH

IN HAM'S LAKE ON 21 MAY 75

\begin{tabular}{|c|c|c|c|c|c|}
\hline \multirow[b]{2}{*}{ Taxa } & \multicolumn{5}{|c|}{ Depth (m) } \\
\hline & 0 & 2 & 4 & 6 & 8 \\
\hline Kellicottia sp. & & & $<1$ & & \\
\hline Keratella sp. & 9 & 6 & 14 & 12 & 13 \\
\hline Lecane sp. & 1 & $<1$ & & $<1$ & \\
\hline Monostyla sp & & 3 & 1 & & $<1$ \\
\hline Asplanchna sp. & 4 & 8 & 2 & 2 & 2 \\
\hline Polyarthra sp. & 8 & 7 & 2 & 2 & 1 \\
\hline Filinia sp. & & & $<1$ & & \\
\hline Conochilus sp. & 215 & 291 & 92 & 81 & 73 \\
\hline Daphnia ambigua & 3 & 5 & 2 & 2 & 4 \\
\hline Daphnia parvula & $<1$ & 2 & $<1$ & & 1 \\
\hline Ceriodaphnia lacustris & 27 & 53 & 20 & 13 & 13 \\
\hline Diaphanosoma leuch. & 12 & 7 & 7 & 2 & 4 \\
\hline Bosmina longirostris & 7 & 4 & 3 & 1 & 3 \\
\hline Kurzia lattisima & $<1$ & & & & \\
\hline Ostracoda & 4 & 13 & 5 & 7 & 24 \\
\hline Nauplii & 48* & $58 *$ & $63 *$ & $69 *$ & $72 *$ \\
\hline Diaptomus pallidus & 12 & 19 & 6 & 3 & 2 \\
\hline Cyclops bicuspidatus & 2 & 3 & 1 & $<1$ & \\
\hline Mesocyclops edax & $<1$ & 7 & 2 & $<1$ & 1 \\
\hline Copepodites & 9* & $18 *$ & $20 *$ & $26 *$ & $23 *$ \\
\hline
\end{tabular}

* See footnote on Table XI. 
TABLE XIII

DENSITY (NUMBERS/1) OF ZOOPLANKTON BY DEPTH IN HAM'S LAKE ON 12 JUN 75

\begin{tabular}{|c|c|c|c|c|c|}
\hline \multirow[b]{2}{*}{ Taxa } & \multicolumn{5}{|c|}{ Depth (m) } \\
\hline & 0 & 2 & 4 & 6 & 8 \\
\hline Branchionus sp. & & & & $<1$ & \\
\hline Keratella sp. & 2 & 3 & 2 & 3 & 1 \\
\hline Monostyla sp. & 1 & $<1$ & & & \\
\hline Asplanchna sp. & 2 & 3 & 3 & & $<1$ \\
\hline Polyarthra sp. & 5 & 9 & 11 & 1 & 1 \\
\hline Synchaeta sp. & & & $<1$ & & \\
\hline Hexarthra sp. & & $<1$ & $<1$ & & \\
\hline Conochilus sp. & 39 & .93 & 25 & 8 & \\
\hline Unident. rotifer & & $<1$ & & & \\
\hline Diaphanosoma 1euch. & 1 & $<1$ & 5 & $<1$ & $<1$ \\
\hline Daphnia ambigua & $<1$ & $<1$ & 1 & & $<1$ \\
\hline Daphnia parvula & & & & & \\
\hline Ceriodaphnia lacustris & 98 & 98 & 36 & 11 & 21 \\
\hline Bosmina longirostris & 9 & 12 & 7 & 2 & 2 \\
\hline Chydoridae & $<1$ & 2 & & & \\
\hline Ostracoda & 3 & 10 & 6 & 7 & 6 \\
\hline Naup1ii & $25 *$ & $28 *$ & $93 *$ & $25 *$ & $15 *$ \\
\hline Diaptomus pallidus & 6 & 10 & 30 & 3 & 3 \\
\hline Mesocyclops edax & 12 & 10 & 13 & 4 & 2 \\
\hline Copepodites & $24 *$ & $19 *$ & $33 *$ & $10 *$ & $15 *$ \\
\hline Chaoborus & & & & & $<1$ \\
\hline
\end{tabular}

* See footnote on Table XI. 
TABLE XIV

DENSITY (NUMBERS/1) OF ZOOPLANKTON BY DEPTH IN HAM'S LAKE ON 2 JUL 75

\begin{tabular}{|c|c|c|c|c|c|}
\hline \multirow[b]{2}{*}{ Taxa } & \multicolumn{5}{|c|}{ Depth (m) } \\
\hline & 0 & 2 & 4 & 6 & 8 \\
\hline Keratella sp. & 33 & 16 & 10 & 4 & 6 \\
\hline Lecane sp. & & 1 & & $<1$ & $<1$ \\
\hline Trichocerca sp. & 4 & 2 & $<1$ & 1 & \\
\hline Polyarthra sp. & 7 & 5 & 2 & $<1$ & 3 \\
\hline Filinia sp. & 2 & $<1$ & & $<1$ & $<1$ \\
\hline Hexarthra sp. & & & 2 & $<1$ & 2 \\
\hline Conochilus sp. & 157 & 88 & 29 & 26 & 35 \\
\hline Unident. rotifer & 6 & 10 & 5 & 2 & \\
\hline Diaphanosoma leuch. & 1 & 11 & 11 & 10 & 11 \\
\hline Daphnia ambigua & $<1$ & 2 & $<1$ & 2 & $<1$ \\
\hline Daphnia parvula & & 1 & $<1$ & $<1$ & \\
\hline Ceriodaphnia lacustris & 18 & 16 & 6 & 5 & 5 \\
\hline Bosmina longirostris & 28 & 19 & 3 & 6 & 2 \\
\hline Ostracoda & 22 & 62 & 12 & 12 & 17 \\
\hline Naupli1 & $73 *$ & $164 *$ & $83 *$ & $75 *$ & $73 *$ \\
\hline Diaptomus pallidus & 12 & 13 & 4 & 1 & $<1$ \\
\hline Cyclops bicuspidatus & & & & & $<1$ \\
\hline Mesocyclops edax & & 6 & $<1$ & $<1$ & \\
\hline Copepodites & $20 *$ & $61 *$ & $38 *$ & $31 *$ & $17 *$ \\
\hline
\end{tabular}

* See footnote on Table XI. 
TABLE XV

DENSITY (NUMBERS/1) OF ZOOPLANKTON BY DEPTH IN HAM'S LAKE ON 3 AUG 75

\begin{tabular}{|c|c|c|c|c|c|}
\hline \multirow[b]{2}{*}{ Taxa } & \multicolumn{5}{|c|}{ Depth (m) } \\
\hline & 0 & 2 & 4 & 6 & 8 \\
\hline Branchionus sp. & $<1$ & & & & \\
\hline Keratella sp. & 16 & 2 & 9 & 4 & 9 \\
\hline Trichocerca sp. & 1 & & $<1$ & & $<1$ \\
\hline Asplanchna sp. & & & $<1$ & & \\
\hline Polyarthra sp. & 3 & 6 & 3 & 3 & 4 \\
\hline Filinia sp. & 2 & & $<1$ & 2 & 5 \\
\hline Hexarthra sp. & 12 & 13 & 16 & 7 & 25 \\
\hline Conochilus sp. & 1 & 2 & & & $<1$ \\
\hline Ceriodaphnia lacustris & $<1$ & & 2 & & \\
\hline Diaphanosoma 1euch. & 1 & 2 & $<1$ & 2 & 6 \\
\hline Ostracoda & $<1$ & 15 & 14 & 8 & 35 \\
\hline Nauplii & $30 *$ & $12 *$ & $6 *$ & $10 *$ & $11 *$ \\
\hline Diaptomus pallidus & & 2 & & & $<1$ \\
\hline Copepodites & $3 *$ & 4* & $1 *$ & $<1 *$ & $3 *$ \\
\hline
\end{tabular}

* See footnote on Table XI. 
TABLE XVI

DENSITY (NUMBERS/1) IN ARBUCKLE LAKE

ON 9 MAY 75

\begin{tabular}{|c|c|c|c|c|c|c|c|}
\hline \multirow[b]{2}{*}{ Taxa } & \multicolumn{7}{|c|}{ Depth (m) } \\
\hline & 0 & 4 & 8 & 12 & 16 & 20 & 24 \\
\hline Keratella sp. & 4 & 35 & 20 & 10 & 8 & 12 & 3 \\
\hline Trichocerca sp. 2 & & & 2 & 2 & 2 & & \\
\hline Asplanchna sp. & 4 & 42 & 13 & 20 & 15 & 9 & 9 \\
\hline Polyarthra sp. & $<1$ & 24 & 10 & 3 & 3 & 4 & $<1$ \\
\hline Filinia sp. & & & & & & & 2 \\
\hline Conochiloides sp. & & 13 & 13 & 3 & $<1$ & & \\
\hline Conochilus sp. & 23 & 347 & 194 & 124 & 133 & 110 & 67 \\
\hline Diaphanosoma 1euch. & & 1 & & $<1$ & & & \\
\hline Daphnia ambigua & & 11 & 2 & $<1$ & & & 1 \\
\hline Daphnia parvula & & 3 & 3 & 3 & 3 & 1 & 4 \\
\hline Ceriodaphnia lacustris & & 3 & 5 & 2 & 1 & $<1$ & 2 \\
\hline Bosmina longirostris & $<1$ & 8 & 4 & 5 & 2 & 1 & 2 \\
\hline Nauplii & $5 *$ & $66 *$ & $60 *$ & $26 *$ & $36 *$ & $14 *$ & $41 *$ \\
\hline Diaptomus pallidus & $<1$ & 1 & 3 & & & & 2 \\
\hline Diaptomus siciloides & ' & & & 7 & 10 & 6 & 10 \\
\hline Tropocyclops prasinus & & 10 & 6 & & $<1$ & & $<1$ \\
\hline Cyclops bicuspidatus & & & 3 & 2 & 2 & 3 & 7 \\
\hline Mesocyclops edax & & 1 & 2 & $<1$ & $<1$ & & \\
\hline Copepodites & $2 *$ & $11 *$ & $21 *$ & $22 *$ & $26 *$ & $12 *$ & $26 *$ \\
\hline
\end{tabular}

*These values included in density totals but not used in determining total number of species or species diversity since they are unidentifiable, immature forms and probably do not represent different species. 
TABLE XVII

DENSITY (NUMBERS/1) IN ARBUCKLE LAKE

ON 22 MAY 75

\begin{tabular}{|c|c|c|c|c|c|c|c|}
\hline \multirow[b]{2}{*}{ Taxa } & \multicolumn{7}{|c|}{ Depth (m) } \\
\hline & 0 & 4 & 8 & 12 & 16 & 20 & 24 \\
\hline Keratella sp. & 52 & 31 & 29 & 35 & 24 & 26 & 27 \\
\hline Trichocerca sp. 1 & 1 & 2 & & 10 & & 14 & \\
\hline Trichocerca sp. 2 & 85 & 73 & 9 & 20 & 22 & 4 & 15 \\
\hline Asplanchna sp. & 2 & 3 & 1 & 2 & 1 & & \\
\hline Polyarthra sp. & 26 & 22 & 6 & 13 & 12 & 13 & 4 \\
\hline Synchaeta sp. & $<1$ & & & & & $<1$ & \\
\hline Filinia sp. & $<1$ & & & & & & $<1$ \\
\hline Conochilus sp. & 2 & 3 & 1 & 1 & 3 & & 2 \\
\hline Diaphanosoma leuch. & & $<1$ & 1 & & & & \\
\hline Daphnia ambigua & & & & 2 & $<1$ & 2 & $<1$ \\
\hline Daphnia parvula & & 1 & & $<1$ & & $<1$ & \\
\hline Ceriodaphnia lacustris & & 12 & $<1$ & 1 & 1 & $<1$ & \\
\hline Bosmina longirostris & 4 & 8 & 2 & 5 & 5 & 5 & 9 \\
\hline Nauplii & $35 *$ & $38 *$ & $29 *$ & $50 *$ & $57 *$ & $46 *$ & $37 *$ \\
\hline Ostracoda & & & & $<1$ & & & \\
\hline Diaptomus pallidus & & $<1$ & & 1 & $<1$ & 1 & 2 \\
\hline Diaptomus siciloides & & & 1 & $<1$ & & & \\
\hline Cyclops bicuspidatus & & & & 2 & & $<1$ & 22 \\
\hline Mesocyclops edax & & 1 & $<1$ & 6 & 1 & 5 & \\
\hline Copepodites & $2 *$ & $5 *$ & $5 *$ & $16 *$ & $16 *$ & $21 *$ & $26 *$ \\
\hline Chaoborus sp. & & & & & $<1$ & & \\
\hline
\end{tabular}

* See footnote on Table XVI. 
TABLE XVIII

DENSITY (NUMBERS/1) IN ARBUCKLE LAKE

ON 21 JUN 75

\begin{tabular}{|c|c|c|c|c|c|c|c|}
\hline \multirow[b]{2}{*}{ Taxa } & \multicolumn{7}{|c|}{ Depth (m) } \\
\hline & 0 & 4 & 8 & 12 & 16 & 20 & 24 \\
\hline Keratella sp. & 6 & 18 & 2 & 10 & 10 & 9 & 8 \\
\hline Trichocerca sp. 2 & & $<1$ & & & & & \\
\hline Asplanchna sp. & 2 & 4 & & 1 & $<1$ & 1 & 1 \\
\hline Polyarthra sp. & 2 & 15 & $<1$ & 7 & 6 & 3 & 4 \\
\hline Filinia sp. & & & & $<1$ & & & \\
\hline Conochilus sp. & 6 & 9 & & & & & \\
\hline Diaphanosoma leuch. & & 2 & & & $<1$ & $<1$ & \\
\hline Daphnia ambigua & & & 3 & $<1$ & $<1$ & & 1 \\
\hline Daphnia parvula & & & & & $<1$ & & $<1$ \\
\hline Ceriodaphnia lacustris & & 4 & 2 & 8 & 4 & 3 & 3 \\
\hline Bosmina longirostris & 4 & 16 & 10 & 11 & 9 & 11 & 13 \\
\hline Nauplii & $40 *$ & $103 *$ & $62 *$ & $64 *$ & $125 *$ & $41 *$ & $65 *$ \\
\hline Diaptomus pallidus & & 10 & 3 & 6 & 6 & 3 & 7. \\
\hline Tropocyclops prasinus & 1 & 2 & 3 & 3 & & 4 & 3 \\
\hline Mesocyclops edax & 2 & 10 & 5 & 5 & 7 & 2 & 6 \\
\hline Copepodites & $21 *$ & $52 *$ & $37 *$ & $37 *$ & $40 *$ & $22 *$ & $24 *$ \\
\hline Harpacticoid copepod & & & $<1$ & & & & \\
\hline Ergasilis chautauquaensis & & $<1$ & & & $<1$ & $<1$ & \\
\hline
\end{tabular}

* See footnote on Table XVI. 
TABLE XIX

DENSITY (NUMBERS/1) IN ARBUCKLE LAKE

ON 8 AUG 75

\begin{tabular}{|c|c|c|c|c|c|c|c|}
\hline \multirow[b]{2}{*}{ Taxa } & \multicolumn{7}{|c|}{ Depth (m) } \\
\hline & 0 & 4 & 8 & 12 & 16 & 20 & 24 \\
\hline Keratella sp. & 10 & 14 & 10 & & 7 & & \\
\hline Trichocerca sp. 1 & & $<1$ & & & & & \\
\hline Trichocerca sp. 2 & & 1 & 1 & $<1$ & $<1$ & & \\
\hline Asplanchna sp. & $<1$ & 1 & $<1$ & $<1$ & & & \\
\hline Polyarthra sp. & 5 & 12 & 7 & $<1$ & 5 & $<1$ & \\
\hline Hexarthra sp. & 1 & 2 & & & & & \\
\hline Conochilus sp. & 2 & 21 & 1 & 3 & 5 & & \\
\hline Diaphanosoma leuch. & & 5 & $<1$ & $<1$ & 2 & & \\
\hline Daphnia ambigua & & & $<1$ & & & & \\
\hline Ceriodaphnia lacustris & & 4 & 3 & 2 & & 3 & \\
\hline Bosmina longirostris & & 11 & 6 & 5 & 5 & 3 & 4 \\
\hline Nauplii & $9 *$ & $47 *$ & $26 *$ & $17 *$ & $20 *$ & $13 *$ & $12 *$ \\
\hline Ostracoda & $<1$ & & & & & & \\
\hline Diaptomus pallidus & & & & & 3 & & $<1$ \\
\hline Tropocyclops prasinus & & 10 & 2 & 2 & 7 & $<1$ & 3 \\
\hline Mesocyclops edax & & 2 & $<1$ & & & & \\
\hline Copepodites & $3 *$ & $45 *$ & $16 *$ & $13 *$ & $21 *$ & $7 *$ & $13 *$ \\
\hline Ergasilis chautauquaensis & & $<1$ & & & & & 1 \\
\hline
\end{tabular}

*See f-otnote on Table XVI. 
VITA

Nancy Lynn McClintock

Candidate for the Degree of

Master of Science

Thesis: EFFECTS OF ARTIFICIAL DESTRATIFICATION ON ZOOPLANKTON OF TWO OKLAHOMA RESERVOIRS

Major Field: Zoology

Biographical:

Persona1 Data: Born in Fort Worth, Texas, October 28, 1951, the daughter of A. Dan and Beverly J. McClintock.

Education: Graduated from Forest Park High School, Beaumont, Texas in May, 1970; received a Bachelor of Science degree in Biology from Lamar University, Beaumont, Texas in May, 1974; completed requirements for a Master of Science at Oklahoma State University, Stillwater, Oklahoma in July, 1976.

Professional Experience: Graduate Teaching Assistantship, Oklahoma State University, August, 1974 to May, 1976; Graduate Research Assistantship, Oklahoma State University, June to September, 1975, and June to September, 1976; Aquatic Ecologist, TechRad Inc., Oklahoma City, Oklahoma, February, 1975 to March, 1975. 